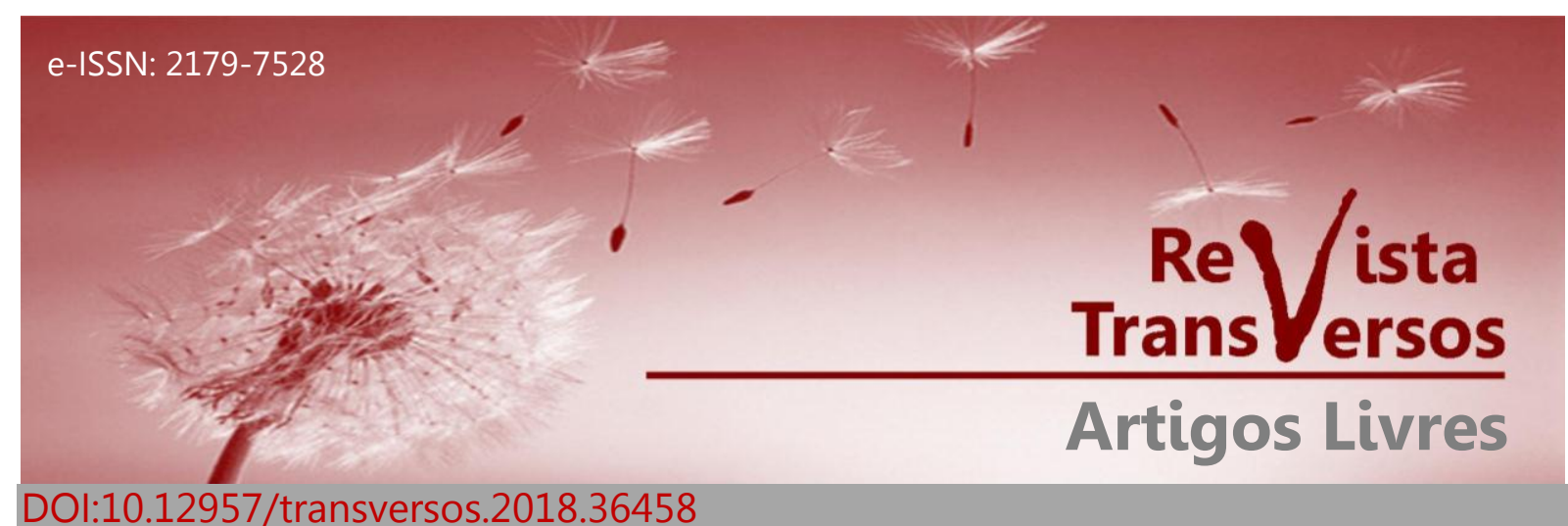

\title{
“TEMPOS DE INQUIETAÇÃO": O CONTEXTO DE 1968 NAS PÁGINAS DA REVISTA A SEARA DA IGREJA ASSEMBLEIA DE DEUS
} "UNRESTING TIMES": 1968'S CONTEXT ON ASSEMBLY OF GOD'S PAGES OF A SEARA MAGAZINE

\author{
André Dioney Fonseca \\ Universidade Federal do Oeste do Pará (UFOPA) \\ andredioney@yahoo.com.br
}

\section{RESUMO}

O objetivo deste artigo é analisar os posicionamentos da revista $A$ Seara, periódico fundado em 1956 e editado pela Casa Publicadora das Assembleias de Deus (CPAD), acerca das agitações que marcaram o contexto de 1968 nos planos nacional e internacional. Considerando que as revistas são um importante espaço para difusão de ideias de determinados grupos, nossa intenção é demonstrar que as críticas da equipe editorial de $A$ Searaaos diferentes movimentos contestatórios que ganhavam visibilidade naquele momento estavam, em muitos aspectos, alinhadas aos argumentos da "Doutrina de Segurança Nacional e Desenvolvimento" (DSND) do regime militar brasileiro.

Palavras-chaves:1968; movimentos sociais; regime militar; $A$ Seara.

\section{ABSTRACT}

The aim of this paper is to analyse the opinions of the magazine $A$ Seara, which was founded in 1956 and edited by the publishing house of the Assemblies of God (Casa Publicadora das Assembleias de Deus - CPAD), regarding the upheavals that marked the year of 1968, both domestically and worldwide. Considering the fact that magazines are important vehicles for the dissemination of ideas of certain groups, our intention is to demonstrate that $A$ Seara's editorial team's critiques to the different protest movements gaining visibility at that time were in many ways aligned with the arguments of the National Security and Development Doctrine (Doutrina de Segurança Nacional e Desenvolvimento- DSND) of the Brazilian military regime.

Keywords: 1968; social movements; military regime; $A$ Seara.

\section{Introdução}

A segunda metade da década de 1960 foi marcada por grandes agitações políticas e sociais nos planos nacional e internacional. Ao Brasil, que havia sido tomado de assalto por um golpe militar, chegavam notícias de movimentos, com

Artigo recebido em 01 de agosto de 2018 e aprovado em 20 de agosto de 2018.

Revista Transversos. Rio de Janeiro. nº 13, MAI-AGO, 2018. 
forte inserção nos meios estudantis, que reivindicavam transformações políticas e culturais. Na política, o alvo era o modo tradicional de governança; no plano dos costumes, desejava-se a garantia de liberdades individuais em uma postura de confrontação direta com o status quo,representada pelas roupas coloridas, pelos cabelos compridos, pela liberação sexual e pelo uso de drogas, sobretudo a maconha e o LSD. O contexto em que fermentaram esses levantes foi assim descrito por Marcelo Ridenti:

As sociedades que viveram certo florescimento político e cultural nos anos 1960 compartilhavam algumas condições materiais, como o aumento e a diversificação das classes médias, a urbanização crescente, a consolidação de culturas e modos de vida típicos das metrópoles, o maior acesso ao ensino superior, a presença expressiva da juventude na composição etária da população, a dificuldade dos poderes estabelecidos para representar sociedades que se renovavam, certa democratização do avanço tecnológico que estabelecia o que então se convencionou chamar "sociedade de consumo". Por si sós, essas condições não explicam a disseminação de movimentos rebeldes e revolucionários em todo o planeta, mas criavam um ambiente propício a diversificadas ações culturais e políticas transformadoras. (RIDENTI, 2007, p. 187).

Em estudo realizado com o sociólogo Ricardo Antunes, Marcelo Ridentiaponta que todo esse espírito de insatisfação que tomou corpo no decorrer da década de 1960 alcançou seu auge em 1968, quando o mundo foi tomado por uma onda de revoltas operárias, estudantis, feministas, de movimentos negros, ambientalistas, homossexuais, entre outros, que selaram o "fim dos anos dourados" (RIDENTI;ANTUNES, 2007, p. 79). Os autores destacam alguns desses movimentos de protesto social e de mobilização política que sacudiram o establishment em diversos países:

[...] o maio libertário dos estudantes e trabalhadores franceses, a"Primavera de Praga" contra o "socialismo real" sob domínio da URSS, o massacre de estudantes no México, as manifestações nos Estados Unidos contra a guerra no Vietnã, as distintas ações revolucionárias armadas em diversos países, os movimentos de contracultura. (RIDENTI; ANTUNES, 2007, p. 79).

No Brasil, em termos de protestos, 1968 nada ficou a dever à conjuntura internacional, ressalvando-se que aqui havia demandas específicas que não devem ser tomadas como corolário dos acontecimentos contestatórios presentes em outros países:

[...] além da influência dos fatores internacionais e da identidade com movimentos contestadores de outros países, o 1968 brasileiro teve 
especificidades. Por exemplo, o nosso movimento estudantil, deflagrado a partir de março, seguiu uma dinâmica de luta específica e um calendário político próprio, anterior ao famoso maio de 1968 na França. Do mesmo modo, as greves metalúrgicas de Osasco (região industrial na grande São Paulo, desencadeada em julho) e as greves de Contagem (região industrial na grande Belo Horizonte, Minas Gerais, deflagradas em abril e outubro do mesmo ano de 1968) encontram suas origens e raízes muito marcadas pela particularidade brasileira, em plena luta contra a ditadura militar. Isso não significa dizer que os brasileiros não estivessem sintonizados com as manifestações que ocorreram mundo afora naquele ano. (RIDENTI; ANTUNES, 2007, p. 79).

Há de se destacar dois movimentos nacionais que, em 1968, passaram a preocupar seriamente o regime militar: o movimento estudantil e o movimento operário. Os estudantes tinham reivindicações pontuais, como ensino público e gratuito universal e reforma universitária que garantisse o acesso e a qualidade do ensino superior, inclusive com maior participação estudantil nas instâncias decisórias e maior fomento para pesquisas que se propusessem pensar soluções para os problemas econômicos e sociais do Brasil. Os acordos do regime militar com a United StatesAgency for InternationalDevelopment (USAID), que ficaram conhecidos como MEC-USAID, também eram alvo da insatisfação da classe estudantil, especialmente pelas propostas tecnicistas e fortemente atentatórias ao caráter público do ensino.Mas havia também uma pauta mais abrangente: "os estudantes também contestavam a ditadura implantada com o golpe de 1964 e o cerceamento às liberdades democráticas" (RIDENTI; ANTUNES, 2007, p. 80).

O movimento operário, que havia sido duramente combatido nos anos que se seguiram ao golpe, retornou no início de 1968 com renovada força. No mês de abril, sindicalistas ligados ao Partido Comunista Brasileiro (PCB) lideraram uma greve na cidade de Contagem (MG) que resultou em uma marcante vitória, pois o governo militar, tomado de surpresa pelo ressurgimento de tão incisiva agitação entre os operários, teve de atender às demandas trabalhistas. Em julho, foi a vez da cidade de Osasco (SP) se tornar palco de mais um grande movimento grevista, só que dessa vez com resultado negativo, pois o aparato militar do governo já estava preparado e a greve foi debelada, sendo todaa liderança duramente reprimida.

Um mês antes da ação grevista de Osasco, a "Passeata dos CemMil", realizada no Rio de Janeiro (junho de 1968), dava mostras de que a própria classe 
média, que havia saudado o golpe, àquela altura já se sentia vítima das ações autoritárias encabeçadas pelo Estado (ALVES, 1989, p. 162). Em outro polo de ação estavam os grupos revolucionários, que se organizavam para a luta armada contra o regime, como a Vanguarda Popular Revolucionária(VPR), o Movimento Revolucionário Oito de Outubro(MR-8), a Ação Libertadora Nacional(ALN), o Comando de Libertação Nacional(Colina) e o Partido Comunista Brasileiro Revolucionário(PCBR).

No cenário político, além dos grupos de esquerda, que sempre estiveram em lado oposto ao do regime militar, o governo tinha de lidar com a insatisfação de personalidades de forte expressão política que haviam apoiado o golpe de 1964, entre eles Carlos Lacerda, que, além de atacar frontalmente o regime, chamando-o de "ditadura corrupta", propunha lançar a Frente Ampla, que uniria, em 1966, diversos políticos, como Juscelino Kubitschek e João Goulart, na oposição conjunta ao governo militar (SKIDMORE, 1988, p. 148-151).

Tendo como base esse efervescente contexto, nosso objetivo neste artigo é analisar os posicionamentos da revista $A$ Seara, periódico fundado em 1956 e editado pela Casa Publicadora das Assembleias de Deus (CPAD), ${ }^{2}$ acerca desses acontecimentos que causavam grande perplexidade em todos os segmentos sociais, políticos e religiosos aferrados à manutenção das tradições e defensores da moral e dos "bons costumes".Nesse sentido, aescolha da revista $A$ Seara para a análise que pretendemos desenvolver justifica-se pelo protagonismo desse periódico nos meios assembleianos e pela composição de sua equipe editorial naquele momento. Como têm demonstrado diversos estudos, as revistas são importantes instrumentos para a difusão de ideias e a defesa de determinados pontos de vista por indivíduos que compartilham posições comuns sobre diversos assuntos. Sobre essa característica, Jean-François Sirinelli afirma:

[...] as revistas conferem uma estrutura intelectual por meio de forças antagônicas de adesão - pelas amizades que as subtendem, as fidelidades que arrebatam e a influência que exercem - e de exclusão - pelas

\footnotetext{
${ }^{2}$ Trata-se da editora pertencente à Assembleia de Deus, Igreja que iniciou suas atividades no Brasil em 1911, por iniciativa de dois missionários suecos, Daniel Högberg e Gunnar Adolf Vingren, e que é uma instituição religiosa do ramo evangélico vinculada ao pentecostalismo. Portanto, todas as referências à Assembleia de Deus, neste texto, dizem respeito ao coletivo de ministérios unidos em torno da Convenção Geral das Assembleias de Deus no Brasil (CGADB).
} 
posiçõestomadas, os debates suscitados e as cisões advindas. Ao mesmo tempo que um observatório de primeiro plano da sociabilidade de microcosmos intelectuais, elas são um lugar precioso para a análise do movimento das ideias. Em suma, uma revista é antes de tudo um lugar de fermentação intelectual e de relação afetiva, ao mesmo tempo viveiro de sociabilidade. (SIRINELLI, 2003, p. 249).

Como bem apontando pelas pesquisadoras Heloisa Cruz e Maria Peixoto, um persistente problema no uso de jornais e revistas nas pesquisas históricas reside nas análises fragmentadas que se fazem da imprensa. Uma reportagem lá, outra acolá, um editorial daqui, outro dali, recolhidos de diversos veículos noticiosos, sem a reinserção na conjuntura e no interior do projeto editorial que thes dava sustentação, configuram-se em um modelo analítico que oblitera toda a dinâmica editorial que está por trás de um jornal ou de uma revista. No dizer das autoras: "Qualquer que seja nosso caminho de aproximação com jornais e revistas em suas diferentes formas históricas, não se pode esquecer que o objetivo de nossa leitura e análise é a de indagar sobre a configuração de seu projeto editorial, desvendando sua historicidade e intencionalidade" (CRUZ;CUNHA, 2007, p. 260).

Por isso, é preciso compreender que todo periódico, seja qual for o segmento que representa, é resultado de uma atividade na qual estão envolvidos jogos de poder, negociações e outras tantas variáveis que incidem diretamente nos elementos textuais e composicionais (LUCA, 2006). Mas, para perscrutar todos esses aspectos, é necessário um olhar multidirecional, capaz de superar uma prática que foi muito comum nas análises da imprensa, qual seja, abordagens em que, quase sempre, as atenções estavam voltadas exclusivamente aos conteúdos dos periódicos, sem considerar as práticas sociais e os agentes envolvidos em sua produção e organização (MARTINS, 2003).

Assim, antes de analisarmos as manifestações de $A$ Seara no contexto de 1968, é preciso que façamos um rápido retrospecto históricopara que o leitor deste texto possa situar qual era o "momento editorial" da revista naquele período. Esse é um exercício analítico que consideramos de suma importância,ainda mais em se tratando 
de uma revista tão longeva, ${ }^{3}$ pois seria mesmo descabido acreditar que a manutenção do título $A$ Seara por longo período fosse, em si, uma garantia de que as políticas editoriaisdessa revista permaneceram inalteradas.

\title{
2. A revista $A$ Seara
}

Fundada em 1956 por João Pereira de Andrade e Silva e Joanyr de Oliveira, em seus primeiros anos de circulação a revista $A$ Seara foi marcada por muitas polêmicas em torno de seu projeto editorial, que, em linhas gerais, tinha como objetivo apresentar uma nova imagem do pentecostalismo como um grupo que tinha em suas fileiras de membros pessoas que se interessavam pela instrução formal escolar e universitária, apreciadores da arte, da literatura, da ciência, enfim, que muitos pentecostais tinham uma vida integrada a distintas esferas da sociedade(FONSECA, 2017).

Desejava-se, para tanto, encontrar uma maneira de dar destaque ao grupo de fiéis da Assembleia de Deus, que reunia pessoas com instrução educacional, universitários de diversas áreas, profissionais bem-sucedidos, indivíduos afeitos à literatura, à poesia, à arte e à cultura em geral. E não era só. Havia ainda uma proposta de incentivoà participação dos membros em atividades políticas, sindicais e agremiações estudantis.Esse conjunto de propostas, bastante ousado para o padrão assembleiano vigente na década de 1950, causou sérios problemas aos fundadores da revista $A$ Seara,que, após uma sistemática pressão de parte da liderança da Igreja, tiveram de deixar a redação do periódico: Andrade e Silva, em novembro de 1957, eJoanyr de Oliveira, em junho de 1958. A situação embaraçosa foi assim descrita por Joanyr de Oliveira em suas memórias:

\begin{abstract}
A reação dos fanáticos ultraconservadores [contra a revista $A$ Seara], tímida a princípio, foi recrudescendo, a "alcunha" de batista (por defender congresso de jovens e educação teológica) e de comunista (pelos que desenterravam sem piedade meu passado e propugnavam sempre por posições antimudancistas) foi ecoando e, por fim, me desestabilizou, apesar das tiragens que colocavam o periódico como o maior dos congêneres em
\end{abstract}

\footnotetext{
${ }^{3}$ A Seara circulou como revista evangélica ilustrada entre setembro de 1956 e outubro de 1980, quando passou a tratar de assuntos inerentes à "família cristã". A revista teve, em sua primeira edição, uma tiragem de 11 mil exemplares; em alguns períodos críticos, teve média de tiragem anual de 3.850 exemplares, como em 1960, mas chegou a alcançar a vultosa tiragem média de 38 mil, no ano 1977.
} 
nosso país [...] fui coagido pelo pastor Túlio Barros Ferreira, de São Cristóvão, sucessor do professor João Pereira, a deixar o cargo de editor, em favor de Alcebíades Pereira Vasconcelos, fraternal amigo do novo responsável pela editora. A perseguição era insuportável, e, a esta altura, eu não contava com ninguém que me desse cobertura. Como Amós, só tinha a lamentar o "não ser filho de profeta". (OLIVEIRA, 2008, p. 30-31).

A partir do desmonte da esquipe fundadora, a revista entrou em uma nova rota editorial,na qual os principais objetivos de João Pereira de Andrade e Silva e Joanyr de Oliveira foram claramente desconsideradosem favor de um novo projeto,com o objetivo de transformá-la em uma revista de conteúdo majoritariamente teológico-doutrinário-evangelístico(FONSECA, 2017). O mentor desse projeto era Emílio Conde, um dos mais proeminentes nomes da CPAD à época e que sempre vira com muitas ressalvas a plataforma primeira de $A$ Seara,o que não é de surpreender, se considerarmos que Conde se notabilizou na história da Assembleia de Deus como um obstinado defensor da prática de um "pentecostalismo genuíno", por sua visão teológico-doutrinária muito austera, pautada pela completa separação entre Igreja e mundo (ALENCAR, 2000, p. 66).

Com esse pensamento, Conde ficou à frente de $A$ Seara de janeiro de 1959 a dezembro de 1968, quando teve de deixar a CPAD para tratamento de uma enfermidade. Esse foi um período em que a nova equipe editorial da revista buscou contornar aquela imagem de $A$ Seara como uma revista "moderna", aberta a divergentes opiniões e promotora de debates acerca de temas que deveriam estar restritos ao escopo das reservadas convenções gerais. Desejava-se também ver superado o objetivo tão caro ao projeto primeiro da revista de concentrar esforços em várias frentes para sobrepujar uma tão cristalizada visão do fiel pentecostal como um indivíduo "ignorante" e apartado da vida em sociedade, até porque essa proposta servia como legitimação para as campanhas em prol de uma maior aproximação da Igreja com a esfera política em que se havia metido $A$ Seara.Nesses novos tempos, a lógica editorial era sintética e pontual: nada de textos (especialmente editoriais) inclinados a polêmicas, sortidos de ácidas adjetivações e carregados de provocações em relação às posturas tidas como inamovíveis pelo conservadorismo assembleiano. ${ }^{4}$

${ }^{4} \mathrm{O}$ fato de $A$ Seara não ter nem sequer mencionado a tomada do poder pelos militares em 1964, embora o golpe fosse visto com simpatia pela Assembleia de Deus, é um bom exemplo de que a 
Emílio Conde teve, contudo, de se afastarda CPAD no fim de 1968 por problemas de saúde, como já foi dito, deixando a revista a cargo dos pastoresAlcebíades Vasconcelos e Geziel Nunes Gomes, figuras que eram de sua inteira confiança, mas que estavam inclinadas a superar esse alheamento de $A$ Seara diante de um contexto tão conturbado como aquele. A saída do severo Conde abriu espaço para uma maior autonomia aos que ficavam na redação, ainda que nada nos autorize a afirmar que o projeto editorial da revista tenha sido lançado ladeira abaixo, pois na redação não ficaram opositores de Conde, ao contrário, lá estavam dois admiradores de seu trabalho. O que se percebe é que houve um alargamento da abrangência temática da revista, permitindo-lhe tratar dos movimentos contestatórios sem se eximir das questões políticas e sociais, dando claros acenos de apoio ao governo militar (FONSECA, 2017).

\section{3. "Tempos de inquietação": o contexto de 1968 nas páginas da revista $\boldsymbol{A}$ Seara}

O editorial de um jornal ou de uma revista é um espaço privilegiado para se acompanhar a opinião oficial do grupo responsável a respeito de diversos assuntos. Conforme destaca Luiz Beltrão, é por meio desse gênero de texto que os grupos detentores de periódicos expressam suas opiniões sobre diversos aspectos da sociedade.Com esse gênero jornalístico, a imprensa expõe sua apreciação sobre aquilo que se desenrola nos mais diversos setores da sociedade:

Tem sempre de tomar partido, pois sua finalidade é aconselhar e dirigir as opiniões dos leitores. Não se pode reservar: tem de decidir-se. O jornal está, por essência, comprometido a dizer em voz alta o que pensa. [...] Está-lhe vedado dar o silêncio por resposta ao interrogatório da atualidade, ou dar uma resposta ambígua (BELTRÃO, 1980, p. 80).

A essas características, já bem conhecidas dos editoriais, Maria Aparecida de Aquino acrescenta outro aspecto. Segundo Aquino, os editoriais, ao defenderem pontos de vista específicos dos grupos, escamoteiam esses "interesses próprios" ao se apresentarem como defensores de causas que seriam significativas para o grande público:

revista, na era Conde, havia assumido uma postura de afastamento do temário político. Para mais detalhes sobre a atuação de Emílio Conde em $A$ Seara,verFonseca (2017, p. 141-197). 
Pode-se argumentar que, ao lado de ser considerado como "o pensamento do jornal", o editorial é também a forma pela qual interesses representados na empresa querem ser mostrados a seu público. Portanto, da mesma maneira que, arvorando-se em "formadores de opinião", divulgam seus pontos de vista como se fossem significativos para o conjunto da população, aqui nos encontraríamos frente a outra forma de ocultação dos interesses "de fato" dos periódicos. (AQUINO, 1994, p. 20).

Olhar para os editoriais como expressão de um "grupo" tem implicações diretas sobre a compreensão do próprio periódico, que deixa de ser um depósito de mensagens e passa a ser entendido como uma força ativa nas disputas empreendidas no campo social. Assim, para a análise que propomos realizar neste estudo, fechamos nosso quadrante analítico nos editoriais de $A$ Seara entre os anos 1969 e 1970.

Com o título "Lares incendiados", o editorial do número 76 da revista, referente aos meses de maio/junho de 1969, mostrava preocupação com a crescente rebeldia dos jovens e,em uma miscelânea de críticas bem típica do conservadorismo assembleiano, atirava para todos os lados: frouxidão dos pais para com seus filhos, espírito de rebeldia dos jovens, má influência dos programas de televisão e também dos "jornais" seculares.

Muitos lares estão em polvorosa. Neste século das luzes as trevas predominam. Desordens em família caracterizam a época agitada, febril e inquietante. Aos milhões, os pais vão perdendo o contrôlesôbre os próprios filhos, numa reviravolta fantástica que ameaça até governos. Há um incêndio negativo, fruto de um fogo que entrou no próprio espírito da juventude do século XX. Esse fogo está queimando a ordem, destruindo a paz, obstruindo os movimentos do Bem, cerceando as legítimas liberdades e absorvendo a energia espiritual, que costumeiramente capacita os homens a raciocinarem com profundidade sobre temas atinentes à vida eterna. Êsse fogo está separando os laços tradicionais de amizade de pais para filhos, rompendoos grosseiramente. Êsse fogo está crepitando nas varandas, nas salas, nos quintais e nas cozinhas. Tradicionais encontros fraternais vão sendo substituídos por solilóquios diante do vídeo ou frente a jornais seculares [...]. (A Seara,p. 2,maio/jun. 1969).

O primeiro detalhe interessante está no trecho que fala dos riscos que essa juventude representava para os "governos". A preocupação com a "rebeldia" da juventude, expressa em $A$ Seara,está diretamente vinculada ao momento vivido no país em 1969. Marcelo Ridenti explica o porquê desse protagonismo da juventude 
estudantil na oposição ao regime militar, contestação que se intensificou a partir do Ato Institucional no 5, o Al-5:

\begin{abstract}
O movimento estudantil tinha tradição de luta na defesa das liberdades democráticas, das reformas de base, principalmente no sentido da conquista da reforma universitária, que implicava, dentre outras coisas, a extensão do ensino público e gratuito e a cogestão nas faculdades, inaceitáveis pelo regime militar. Essa tradição do movimento, a repressão governamental numa conjuntura de relativa liberdade de ação, entre 1965 e 1968, bem como a agitação cultural do período e a crise econômica que se vivia, tudo isso contribuía para que as tendências de esquerda encontrassem público entre os estudantes, que iam aderindo à militância clandestina no correr do tempo, dedicando-se exclusivamente a ela depois do "fechamento" total do Al-5, que não deixava lugar para a luta nas escolas, nem para as lideranças, nem para as massas universitárias. (RIDENTI, 1993, p. 125).
\end{abstract}

A redação de $A$ Seara mostrava-se amedrontada com o espírito de inquietação da juventude e, fazendo eco ao alarmismo bem comum daquele período (MARTINS FILHO, 1987; LANGLAND, 2013), via nele um canal capaz de "destruir" a "paz" e a "ordem", pondo em situação de risco o funcionamento do país. O editorial foi bem direto nesse ponto: esses jovens descritos como "agitados", "febris" e "inquietos" representavam uma verdadeira ameaça aos governos, o que de, certa maneira, acabava confluindo com o que era dito pelos militares quando buscavam legitimação para o endurecimento das políticas persecutórias de combate aos "agitadores" de diferentes matizes. Segundo o editorial, em seus levantes esses jovens insatisfeitos nada mais faziam do que obstruir os movimentos do bem e cercear as legítimas liberdades, entendendo-se esse "bem"e essa"liberdade"como elementos que só poderiam ser garantidos pelo grande ordenador da vida em sociedade: o Estado.

De maneira muito sutil, tocava-se em uma questão de grande importância para o quadro político do Brasil daquele momento: a "Doutrina de Segurança Nacional e Desenvolvimento" (DSND). Essa doutrina tinha tamanha importância para o regime militar que a pesquisadora Maria Helena Moreira Alves (1989) defende que o Estado brasileiro, após o golpe de 1964, deva ser caracterizado como "Estado de Segurança Nacional e Desenvolvimento", visto que as ações administrativas levadas a efeito pelos militares - não só aquelas de repressão, mas também as decisões na 
área econômica do país - seguiam a lógica do binômio "segurança/desenvolvimento".

Em plena vigência do Al-5, decretado em dezembro de 1968, o Estado autoritário brasileiro estava disposto a eliminar quaisquer forças oposicionistas que ameaçassem o governo da "Revolução". Daí a contribuição que a nova equipe editorial de $A$ Seara esperava dar, chamando a atenção dos pais que, ao não controlarem seus filhos, prestavam um desserviço não só à formação espiritual dos jovens, mas também à segurança coletiva da nação. O problema estava nos lares, portanto, em que a formação cristã perdia espaço para o televisor e para os jornais e revistas seculares.

No caso específico da televisão, não há como deixar de apontar certa desarmonia na crítica formulada por um editorial que queria se colocar ao lado do governo, pois, se a causa dessa desordem dos jovens tinha, de fato, relação com a "invasão" dos lares do paíspelos televisores, o próprio governo teria, então, grande parcela de culpa como principal fomentador que foi da expansão de redes de televisão por todas as regiões do Brasil, pois, como é sabido, o Estado autoritário brasileiro nem de longe achava que a presença de televisores nos domicílios representasse perigo, desde que, obviamente, o conteúdo produzido pelas emissoras fosse controlado e as concessões das redes fossem entregues nas mãos de empresários e/ou políticos aliados ao regime. ${ }^{5}$

Assim, cautelosos por se tratar de assunto que dizia respeito a uma política de governo, os responsáveis por $A$ Seara reservaram-se em lançar a crítica à TV sem relacioná-la com a lógica governamental que, naquele momento, era claramente favorável à abrangência da transmissão de sinais televisivos por todo país. Por isso, limitara-se a dizer: "Tradicionais encontros fraternais vão sendo substituídos por solilóquios diante do vídeo ou frente a jornais seculares [...]"( $A$ Seara,p. 2, maio/jun. 1969).

\footnotetext{
${ }^{5} \mathrm{Na}$ verdade, como salienta Esther Hamburger, as telecomunicações eram consideradas estratégicas na política nacional de desenvolvimento e integração no pós-golpe de 1964. Como faz recordar essa autora: "os militares investiram na infraestrutura necessária à ampliação da abrangência da televisão e aumentaram seu poder de ingerência na programação por meio de novas regulamentações, forte censura e políticas culturais normativas" (HAMBURGER, 1998, p. 454).
} 
Outra grande preocupação do momento, que acabou reverberando nas páginas de $A$ Seara, era a opção pela luta armada. Como destaca o historiador Daniel Aarão Reis Filho(2000, p. 52): "[...] entre 1969 e 1972, desdobraram-se ações espetaculares de guerrilha urbana: expropriações de armas e fundos, ataques a quartéis, cercos e fugas, sequestros de embaixadores". ${ }^{6}$ Não por acaso, o tema da inquietação voltaria às páginas da revista nos números 83 (março de 1970) e 84 (abril/maio de 1970), sendo tratado de forma mais direta em comparação à abordagem dada no editorial "Lares incendiados" de maio/junho de 1969.

Começaremos analisando o editorial referente ao número de abril/maio de 1970, porque, nele, a redação de $A$ Seara esboça preocupação direta com a luta armada. O foco do texto eram os grupos sociais insatisfeitos com o governo, que praticavam sequestros e assaltos a bancos, ações interpretadas como a expressão máxima de um estado de desordem que tomava conta de uma sociedade cada vez mais guiada pelo espírito de "inquietação":

Inquietação
"O homem nascido da mulher, é de bem poucos dias e cheio de
inquietação". Jó 14:1
INQUIETAÇÕES, de acordo com o texto que transcrevemos de Jó, sempre foi
uma característica do homem, em seu viver sôbre a terra. No entanto,
levando-se na devida consideração o que vai pelo mundo na atualidade,
reconhecemos, mais do que nunca, em sua existência, o homem vive cheio
de inquietações. Qual é o país do universo, civilizado ou bárbaro, rico ou
pobre, desenvolvido ou subdesenvolvido, onde não há inquietação?
Reconhecemos com tristeza, porém a bem da verdade, que êsse problema
cada dia que se passa na voragem dos tempos, ao invés de marchar para a
solução, torna-se mais insolúvel! Seqüestros de aviões, seqüestros de
diplomatas com fins políticos, em vários países; seqüestros de crianças e de
cidadãos pacatos, com fins rapaces; assaltos a Bancos, a Quartéis e a
indivíduos, golpes e contragolpes, espionagem e contra-espionagem, falsos
rumores e coisas semelhantes, constam do noticiário dos jornais e rádios de

6 Tadeu AntonioDix Silva explica como se deu essa opção pela luta armada como instrumento de oposição ao Estado autoritário brasileiro: "O Partido Comunista Brasileiro (PCB)[,] que havia sido severamente atingido pelos golpistas, após um período de reorganização de suas estruturas, encetou um processo de avaliação da autoproclamada Revolução de 31 de Março. $O$ PCB, então, escolheu os canais institucionais - por mais deteriorados que estivessem - objetivando conquistar a redemocratização do Brasil, em coerência com sua estratégia geral de transição pacífica ao socialismo. Em contraposição a estas teses, surgiria a 'nova esquerda' ou 'esquerda revolucionária', conformada por uma constelação de organizações clandestinas fundamentalmente inspiradas nas vitórias das Revoluções Cubana e Chinesa, e no exemplo da Guerra do Vietnã. Portadora de um projeto socialista para a sociedade brasileira, a 'nova esquerda' preconizava a derrubada dos militares e seus aliados civis do governo através de uma ofensiva revolucionária, que aconteceria por meio da luta armada ou insurreições de massa, e posterior implantação de um regime socialista no Brasil" (SILVA, 2007, p. 17). 
todos os países do mundo. A inquietação se apoderou do homem como um todo, e livrar-se dela é do que necessita o homem! Porque enfim, tôda a inquietação humana e vã, e resulta inútil aos inquietadores e aos inquietados, isto é, ao que promove e ao que sofre a inquietação.( $A$ Seara,p. 2, abr./maio 1970).

O que mais chama atenção no editorial é a tentativa de demonstrar ao leitor que o estado de "inquietação", conforme expresso no livro de Jó, era algo inerente à própria natureza humana e não era exclusividade desse ou daquele país, pouco importando se fosse ele rico ou pobre, "civilizado" ou "bárbaro". O que parece ser um mero detalhe na construção da argumentação, na realidade, revela um recurso de deslegitimação dos movimentos que se contrapunham frontalmente ao Estado autoritário brasileiro: havia uma inclinação do homem, como prenunciado pela "Palavra de Deus", a toda sorte de "inquietações", independentemente do nível de desenvolvimento da nação e de suas opções político-administrativas.

Como desenlace dessa situação, o que se via era um quadro social e político agravado pelas ações de grupos formados por homens e mulheres que arriscavam suas vidas porque estavam tomados por um espírito de inquietude. Não eram "inquietos" sem causa, todavia. Para o editorial, os "rebeldes" queriam "subverter" a "ordem", negando o ordenamento político e administrativo da nação com base em "ideologias revolucionárias" que insistentemente queriam se "infiltrar no país". As críticas direcionadas por esses grupos às desigualdades sociais - que, de fato, foram acentuadas pela lógica administrativa dos generais-presidentes - e ao autoritarismo do Estado, que rompeu com o processo democrático por meio de um violento golpe, foram ignoradas no editorial, justamente porque eram vistas, em conjunto, como um "falso" pretexto para a inserção de valores ameaçadores da "ordem" e da "segurança nacional".

Nessa perspectiva, a existência de grupos que se opunham frontalmente ao governo não era um indicativo de que o modelo de administração dos militares estava mostrando suas fragilidades. O problema não estava no Estado, mas no ideário alimentado por essas organizações que afrontavam o governo, sobretudo aquelas que optavam pelo enfrentamento armado. 
O editorial do número 83 de $A$ Seara (março de 1970) seguia essa mesma lógica de preocupação com os atos contra o governo. Sua intenção era trazer uma mensagem direta à "juventude cristã" sobre os perigos que pairavam em tempos marcados pela polarização entre o governo e diversas frentes contestatórias, principalmente pelo risco de os jovens cristãos serem "aliciados" pelas forças antigoverno. Detalhe importante: o texto não se dirigia apenas aos jovens assembleianos; pelo contrário, queria-se portador de um alerta que atingisse toda a juventude ligada ao cristianismo, sem qualquer distinção - algo bem raro na tradição assembleiana, que, com seu histórico senso de exclusivismo, buscava se apartar de todas as tendências ecumênicas. Vajamos o conteúdo do editorial:

\begin{abstract}
Atenção juventude cristã
"Tu pois, permaneceis naquilo que aprendeste e de que fostes inteirado, sabendo de quem o aprendestes". II Tm. 3:14. Caro jovem cristão, Coube-te existir e viver na terra em uma época confusa, época de mudanças e de inquietudes sociais, época de insatisfação e de descontentamento, época de rebeldia e de levantes, de amotinações e revoltas, muitas vêzes injustificadas. Tais coisas, conforme é notório, não se verificam num recanto da terra, ou numa nação isolada, muito ao contrário, são algo do cotidiano, com que estão se havendo tôdas as nações e povos do mundo. E, de certo modo, é você, meu caro jovem, o elemento diretamente visado pelos agitadores, como elemento capaz de ser por êles usado, a semelhança [sic] de um cavalo de batalha, posto em campo como ativista, nesta campanha inglória movida contra os Poderes e os sistemas constituídos de nossa Pátria querida. Daí nossa chamada de atenção a você, amado jovem cristão, a fim de aconselhá-lo a se prevenir e estar sob aviso contra êsses pretensos "salvadores da Pátria", que na realidade nada mais são do que autênticos traidores dela, pois apenas servem de instrumentos servis a "poderes" estranhos que se propõem a conquistar, dominar e escravizar a nossa Pátria. Leia uma vez mais o texto bíblico que usamos na introdução a êste editorial e atente bem para as verdades constantes do ensino que êle nos dá. Você, jovem amigo, tem sido instruído na verdade do Evangelho de Cristo, que é o poder de Deus para a salvação daquele que nêle crê; tem aprendido dêle o dever de obedecer as Autoridades constituídas e está inteirado de que jamais terá um paraíso na terra pois está escrito que "no mundo tereis tribulações". Jo. 16:33. Cremos firmemente, que a tribulação constante do texto citado, não somente diz respeito à vida espiritual, também se refere as limitações, [sid aos problemas e as tristezas [sid] e penúrias próprias desta vida humana e perecível que aqui vivemos. No entanto, você sabe de quem aprendeu a verdade que Êle disse: "tende bom ânimo", e por isto nunca deve desanimar, e sim avançar firme em sua conduta cristã, certo de que a vitória lhe está assegurada para a eternidade. Sim, mantenha ânimo, certo de que você, permanecendo assim em Cristo, sem se deixar insinuar por doutrinas errôneas tenham as cores que tiverem e sem se imiscuir em coisas duvidosas, com toda certeza será um autêntico vencedor pois "esta é a vitória que vence o mundo: a nossa fé em Jesus" I Jo. 5:4. (A Seara,p. 2, mar. 1970).
\end{abstract}


Ao reafirmar a preocupação com os jovens, $A$ Seara mostrava-se alinhada ao discurso do governo naquele momento,segundo o qual, sob a vigência do $\mathrm{Al}-5$, o Estado autoritário lutava em declarada guerra contra toda sorte de foco oposicionista, sem qualquer restrição aos meios utilizados nesse combate. É importante destacar que os militares faziam questão de classificar as ações contra os chamados "subversivos" como sendo uma guerra, esperando, com essa modelagem de um ambiente caótico, fundamentar práticas violentas que escapavam de regulamentos protocolares - a generalização da prática da tortura é um exemplo claro disso (MAGALHÃES, 2004; MATTOS, 2003; AQUINO; MATTOS; SWENSSON JR., 2002; JOFFILY, 2013). Agindo assim, mesmo diante da flagrante desproporcionalidade de força entre o Estado autoritário e os grupos armados de oposição, o governo militar encontrava as justificativas necessárias para todo um conjunto de arbitrariedades que alcançavam, inclusive, oposicionistas que não se vinculavam à luta armada.

Aspecto que se deve ressaltar é que o editorial compartilhava essa ideia oficial de que havia uma excepcionalidade naquela conjuntura nos planostanto nacional quanto internacional. Eram tempos de "mudanças", de "inquietudes sociais", de "insatisfação" de "descontentamento", de "rebeldia", de "levantes", de "amotinações" e de "revoltas", que redundavam em movimentos sem nenhuma justificativa plausível. O problema era ainda mais preocupante porque esses "agitadores" tinham grande interesse pela força jovem em suas fileiras de luta. A ideia era, portanto, mostrar à juventude cristã que ela não deveria se deixar levar pelos discursos daqueles que moviam uma campanha "inglória" contra os "poderes" e os "sistemas constituídos" da "pátria querida".

O jovem, assim, deveria estar prevenido contra os que a ele chegassem propondo qualquer forma de ação que fosse de encontro às autoridades, sob pena de também se tornar, à semelhança dos muitos revoltados, um verdadeiro "traidor da Pátria". Essa classificação dos indivíduos ligados a grupos de oposição ao governo como "traidores da Pátria" merece ser sublinhada, pois novamente temos aqui uma imbricação dos argumentos utilizados pela revista com as ideias presentes no Al-5 e, 
por extensão, com a DSND. Colocar-se contra o Estado, ou melhor, contra seu representante máximo, o Executivo, significava não uma traição ao governo em si, mas um ato profundamente insidioso à nação! Aí estava a figura do "inimigo interno", expressão abrangente talhada pelo Estado autoritário para caracterizar todos os que discordavam dos rumos dados à nação no sistema político encabeçado pelo generalato. Maria Helena Moreira Alves contribui para o entendimento dessa lógica:

\begin{abstract}
A teoria da Segurança Interna dota o Estado de Segurança Nacional de ampla justificação para o controle e a repressão da população em geral. Pode-se mesmo dizer que fornece um incentivo moral, já que a rigorosa manutenção da Segurança Interna é a missão comparável à defesa do país da ocupação de um exército estrangeiro. Além disso, o caráter oculto da ameaça torna praticamente impossível estabelecer limites para as ações repressivas do Estado e dos poderes militares. O próprio Estado de Segurança Nacional - e frequentemente seus setores mais intimamente ligados ao aparato repressivo - determina em última instância que é o "inimigo interno" do país, e que atividade de oposição constituem "antagonismo" ou "pressões". Desse modo, a reponsabilidade pelo controle das atividades subversivas ou revolucionárias dota as forças militares de poderes praticamente ilimitados sobre a população. É evidente que semelhante doutrina põe em sério risco a defesa dos direitos humanos. Quando é impossível determinar com exatidão quem deve ser tido como inimigo do Estado e que atividades são consideradas permissíveis ou intoleráveis, já não haverá garantias para o império da lei, o direito a defesa ou a liberdade de expressão ou de associação [...] todos os cidadãos são suspeitos e considerados culpados até provarem a sua inocência. Tal inversão é raiz e causa dos graves abusos de poder que se verificam no Brasil. (ALVES, 1989, p. 40).
\end{abstract}

Para o editorial, esse "inimigo" da pátria, descrito como "traidor", era uma figura solerte, que, a mando de "poderes estranhos", queria "escravizar a nação", e, na busca desse objetivo, manipulava jovens incautos como quem doma uma cavalgadura. Destaque para a depreciação dos jovens que se aliavam a esses grupos: eram apenas "cavalos de batalha", portanto, sem nenhuma noção do que faziam, sem aspiração alguma, guiados tão somente pela lábia fraudulenta dos que lideravam esses movimentos.

Esse raciocínio de que os tais "poderes estranhos" fisgavam as mentes dos jovens, tal como desenvolvido no editorial de $A$ Seara,era também franqueado pela DSND, cuja propagação no Brasil se dava pela Escola Superior de Guerra (ESG), com forte influência no currículo das demais escolas de formação militar, inclusive na 
Escola de Comando de Estado-Maior (Eceme). Os currículos dos centros de formação militar indicavam que a batalha "revolucionária comunista" acontecia por meio de duas frentes igualmente perniciosas: uma direta,por meio das armas, pela via a guerrilha ou "terrorismo" - que utilizava na luta armada o próprio cidadão da nação que se queria conquistar; e outra indireta, ligada à "conquista das mentes", expediente comunista voltado a superlativar problemas enfrentados pelo povo para pô-lo contra os governantes (ALVES, 1989, p. 38).

Essas ideias não ficavam circunscritas somente aos círculos de formação militar; eram, isso, sim, propagadas pelo Estado autoritário brasileiro e serviam de embasamento para a formulação de leis e decretos, como o próprio Al-5. A redação de $A$ Seara,representada por Alcebiades Pereira de Vasconcelos e Geziel Nunes Gomes, estava afinada comessemodo de pensar e mostrava-se conhecedora dessa teoria na qual os "inimigos" da pátria "conquistavam" adeptos confrontando-lhes com os problemas que vivenciavam no dia a dia. Em harmonia com o fraseado dos militares e seus apoiadores, o editorial buscou uma maneira própria de conscientização dos jovens contra as investidas dos "conquistadores de mentes". E a Bíblia Sagrada, sendo a "palavra de Deus", haveria de dar a resposta para sossegar os ânimos da juventude tão propensa à revolta.

A mensagem que deveria acalmar toda a exaltação juvenil por dias melhores estava centrada no vértice de duas importantes linhas de compreensão bíblica há muito cultivada pela Assembleia de Deus: 1) a obediência às "autoridades" e 2) a certeza de que o cristão nada deveria esperar deste mundo, senão tribulações. De que valeria se levantar contra o governo por melhores condições de vida se os "problemas", as "tristezas" e as "penúrias" eram fatos incontornáveis? Esse tipo de aspiração, portanto, traria consigo um duplo equívoco: colocar-se contra um estado de sofrimento já previsto na Bíblia e, por extensão, atentar contra o mandamento bíblico de sujeição aos governantes. Ou seja, um retumbante erro.

As dificuldades enfrentadas no cotidiano pela população, nessa linha de raciocínio, não poderiam ser atribuídas aos governantes que ocupavam esses postos, porque Deus assim permitiu. As palavras de São João eram claras nesse sentido "no mundo tereis tribulações"(BÍBLIA, 1966)—, de maneira que o importante era que 
os jovens e todos os demais cristãos soubessem da impossibilidade de haver um "paraíso" neste mundo.

O que é contrastante nesse raciocínio - considerando que $A$ Seara era um veículo ligado a uma Igreja sabidamente constituída por uma maioria de membros provenientes dos extratos mais pobres da sociedade- é o fato de ele se apresentar nas páginas da revista no momento em que o Brasil do dito "milagre econômico" vivia o aprofundamento dos índices de desigualdade social. Mas isso nada tinha de novo na tradição assembleiana; a novidade, aqui, estava na forma desnudada com a qual a revista reproduzia uma velha postura tão reveladora do pragmatismo das alas majoritárias da Assembleia de Deus que pode assim ser resumida: a prioridade estava em manter sempre uma "boa relação" com os poderes governamentais, mesmo que para isso tivesse de desincentivar qualquer atitude de reflexão por parte de seus membros a respeito dos problemas sociais que os afligiam no dia a dia.

E esses problemas eram muitos no governo de Emílio Garrastazu Médici, pois os trabalhadores viam seu poder de compra esmagado por uma política de arrocho salarial pensada para tornar o país mais "competitivo", enquanto uma crescente multidão de miseráveis, abandonados à própria sorte pelo Estado autoritário, tão interessado em "investimentos estratégicos", ficava totalmente à margem do "Brasil que ia bem" (PRADO; EARP, 2003).Falando dos anos que precederam a publicação do Al-5, Maria Hermínia Tavares de Almeida e Luiz Weis chamaram atenção para o quadro alarmante de desigualdade social que surgiu da combinação de autoritarismo e crescimento econômico:

O aprofundamento do autoritarismo coincidiu com, e foi amparado por, um surto de expansão da economia — o festejado "milagre econômico" — que multiplicou as oportunidades de trabalho, permitiu a ascensão de amplos setores médios, lançou as bases de uma diversificada e moderna sociedade de consumo, e concentrou renda a ponto de ampliar, em escala inédita no Brasil urbanizado, a distância entre o topo e a base da pirâmide social. (ALMEIDA;WEIS, 1998, p. 332-333).

Diretamente atingido pelas mazelas dessas desigualdades sociais gritantes daquele Brasil que crescia economicamente para uns poucos privilegiados, o trabalhador e a trabalhadora da Assembleia de Deus, às voltas com sua sobrevivência, deveria se contentar com aforismos que lhes consignavam uma vida 
melhor somente em um outro plano, o celestial. É o que fez o editorial de março de 1970 de $A$ Seara,ao aconselhar: "'tende bom ânimo' [...] certo de que a vitória lhe está assegurada para a eternidade" ( $A$ Seara,p. 2, mar. 1970).

Se assim não procedesse, o fiel estaria, então, desobedecendo a Deus, que, por meio de São João, houve por bem avisar seus filhos de que na Terra não deveriam esperar mais do que sofrimento e desventura. Quanto ao jovem, em específico, para que se meter em movimentos contestatórios que lhe sugerissem melhoria de vida se ele poderia canalizar suas forças para as "coisas de Deus", para a salvação de sua alma?

As reflexões sobre os pontos de vista expressos nesse editorial de $A$ Seara ficam mais interessantes se trouxermos para esse debate autores preocupados em observar o contexto do "milagre econômico" como um período em que o autoritarismo e o aprofundamento das desigualdades sociais mesclavam-se com uma forte sensação de otimismo, pois, como aponta Hannah Arendt, "jamais existiu um governo baseado exclusivamente nos meios de violência" (ARENDT, 2004, p.128). Se essa lógica se aplica ao primeiro quinquênio do regime militar brasileiro, ela se aprofunda ainda mais no contexto do "milagre brasileiro", quando, segundo Thomas Skidmore, ganhou força a sensação de que o crescimento econômico e a garantia da "ordem" eram frutos da condução firme do general-presidente Emílio Garrastazu Médici:
A face do presidente Médici tornou-se rapidamente conhecida dos brasileiros como peça central de uma astuta estratégia de relações públicas. O novo governo transmitiu a mensagem de que o Brasil estava velozmente se transformando em potência mundial, graças aos seus 10 por cento anuais de crescimento econômico e à intensa vigilância do governo contra os negativistas e os terroristas. Muitos brasileiros naturalmente concluíram que o aumento do poder nacional conjugado com rápido crescimento da economia era resultado do autoritarismo vigente. (SKIDMORE, 1988, p. 221).

De acordo com Marcos Napolitano (2015), a máxima "nunca fomos tão felizes", um slogan oficial do governo Médici, permite uma leitura ambígua: "como exclamação, traduz uma sensação de felicidade coletiva inédita. Por outro lado, se dita em tom irônico, coloca em dúvida o próprio sentido propagandístico da frase" (NAPOLITANO, 2015, p. 147).Para o autor, essa ambiguidade demonstra muito bem as contradições das medidas econômicas do regime militar brasileiro, especialmente 
no período do governo Médici, que, arrimado nas sombrias diretrizes do Al-5, utilizava-se de toda uma engenharia publicitária para passar uma imagem otimista de que o Brasil vivia tempos "gloriosos": "era a materialização do projeto Brasil Grande Potência, o auge da utopia autoritária da ditadura, que não deixou de seduzir grande parte da população e da mídia" (NAPOLITANO, 2015, p. 162).

Se esse clima de "otimismo" e expectativa com o futuro é um aspecto que não pode ser negligenciado quando voltamos nossa atenção para o contexto do "milagre econômico" (CORDEIRO, 2009), o que podemos dizer sobre as ideias defendidas no editorial "Atenção juventude cristã"? O que se vê é que o texto acaba reforçando a complexidade das percepções daquele momento, pois, em suas linhas, fica bastante claro que a redação de $A$ Seara, no afã de desestimular qualquer tipo de ação contestatória por parte de seus membros (especialmente dos jovens) às "autoridades", optou por uma rota que ia na contramão da euforia com o país do futuro. Isso porque a argumentação do editorial estruturava-se na ideia de que o estado de aflição, conforme assegurava o texto bíblico, era condição imanente à vida terrena.

Ademais, na interpretação teológica assembleiana, de forte acento apocalíptico, não havia espaço para grandes exercícios prospectivos, nem mesmo para expectativas por tempos melhores, primeiro pela ideia de que a volta de Cristo era iminente, e segundo porque os problemas que afligiam o mundo eram incontornáveis e tendiam a se aprofundar exatamente por serem tidos como sinais da proximidade do arrebatamento.

Nisso os "discípulos" de Emílio Conde, Alcebiades Pereira de Vasconcelos e Geziel Nunes Gomes, não pareciam tergiversar, mesmo em um momento de grande esperança no futuro proporcionado pelo "milagre brasileiro". É o que aponta parte do editorial "Que tempos são estes?", publicado em junho de 1970, logo na sequência dos editoriais "Atenção juventude cristã" e "Inquietação", portanto:

Que tempos são estes?

"[...] Muitos correrão de uma parte para outra, e a ciência se multiplicará" Dn $12: 4$

QUE TEMPOS são estes em que vivemos atualmente no universo? Cremos, estes são os tempos do fim da dispensação da graça salvadora de Deus, para 
êste mundo desvairado e corrupto, que se nega de ouvir e se opõe a Deus e ao Seu reino. Jovem amigo, senhor ou senhora que nos lês, a ti é dado o privilégio de viver na terra na antivéspera do arrebatamento da Igreja, nestes tempos do fim, é a ti que nos queremos dirigir para dizer-te o seguinte: Os nossos irmãos do passado, viveram e morreram, pensando, orando, trabalhando e esperando por êsses tempos e se preparando para o arrebatamento da Igreja. Êles souberam perseverar na fé e souberam viver a sua vida cristã de modo a vencer o mundo de sua época e deixar-nos o exemplo vibrante de sua vitória, a vitória de sua fé em Jesus, que os fêz triunfar sôbre as tentações, sôbre o pecado, sôbre o mundo e sôbre o demônio. Agora, quando mais do que nunca nos aproximamos daquele glorioso momento quando a Igreja fiel, a Igreja verdadeira e vencedora será arrebatada da terra e transportada nas asas do Espírito para a imediata presença do seu amado Jesus, é precisamente êste tempo, o tempo da tua oportunidade, os tempos em que te são dados, a viver na terra e provar de quanto és capaz! Dentre todos os sinais proféticos que denunciam êstes tempos, está evidente atualmente mais que nunca, aquêle que transcrevemos do livro de Daniel para a base destas notas: a correria atual, as investigações científicas, a proliferação das idéias humanas e a multiplicação das ciências, dizem numa linguagem eloquente e positiva, e o fazem em altos brados, exclamando: Alerta! Cristo está as portas! Prepara-te para O encontrar!(A Seara,p. 2, jun. 1970).

Se o tal "milagre" lograra espalhar o otimismo para o futuro em diversas parcelas da população brasileira, pelo menos nas páginas de $A$ Seara esse espírito otimista era, em alguns momentos, relativizado. Pelo que se vê, na direção de Alcebiades Pereira de Vasconcelos e Geziel Nunes Gomes remanescia com muita força aquela visão escatológica tão cultivada por Emílio Conde nos muitos anos que esteve na CPAD e no comando da redação de $A$ Seara, de um modo tal que a própria euforia daquele contexto era interpretada como evidente sinal da aproximação do arrebatamento da Igreja.

O fiel, nesse caso, ficava em uma situação que exigia vigilância constante. Por um lado, se seu olhar se voltasse para os graves problemas sociais que afligiam a maior parte da população, ele não poderia se abater, nem mesmo esperar grande melhorias, considerando-se que o sofrimento no mundo era apenas o cumprimento de algo expresso na "Palavra de Deus".Por outro, não deveria se entusiasmar com a possibilidade de um futuro melhor neste mundo, mesmo que a realidade do momento lhe apontasse tal perspectiva, uma vez que o arrebatamento da Igreja estava às portas e todos deveriam se concentrar na salvação da alma e na garantia da vida eterna. 


\section{Considerações finais}

Do que apresentamos neste artigo, pode-se notar que a chegada de novos editores à revista $A$ Seara trouxe alterações significativas na maneira de o periódico analisar o conturbado contexto de 1968. Geziel Nunes Gomes e Alcebíades Pereira de Vasconcelos, ao contrário dos anos anteriores, em que a revista evitou emitir opiniões sobre o que ocorria no cenário político e social do país, passaram a emitir críticas, em alguns momentos de forma contundente, e chegaram até mesmo a dar mostras de simpatia e apoio aos militares instalados no poder. Os novos editores, contudo,tiveram o cuidado de não fazer da revista uma portadora contumaz de propagandas das ações do governo, pois sabiam que uma atitude como essa seria mal vista pelos que não aceitavam a mistura da Igreja com o mundo da política, além de representar uma traição ao emérito redator-chefe Emílio Conde, que considerava inaceitável esse tipo de exposição em um periódico da Igreja.

Ciosos de que não poderiam transformar essa exposição de contentamento com o governo em uma prática corriqueira, os substitutos de Emílio Conde foram, lentamente, dando suas pinceladas em um painel que deveria estampar, sem gerar polêmicas internas, o apoio da Assembleia de Deus às atitudes tomadas pelo Estado autoritário brasileiro em um momento de aprofundamento das medidas que atentavam contra os direitos básicos dos cidadãos. Esperava-se, com isso, que as autoridades tivessem clareza de que tinham na Assembleia de Deus uma entusiasta e uma aliada de primeira hora para todas as bandeiras administrativas que vinham sendo defendidas pelo governo, o que colocava a Igreja em uma posição confortável tanto para a manutenção de suas atividades quanto para eventuais reivindicações.

\section{Referências bibliográficas}

ALENCAR, Gedeon Freire de. Todo poder aos pastores, todo trabalho ao povo, todo louvor a Deus. Assembléia de Deus - origem, implantação e militância (1911-1946). Dissertação (Mestrado em Ciências da Religião), Universidade Metodista de São Paulo, São Bernardo do Campo,2000.

ALMEIDA, Maria Hermínia Tavares de; WEIS, Luiz. Carro-zero e pau-de-arara: o cotidiano da oposição de classe média ao regime militar. In: NOVAIS, Fernando Antonio; SCHWARCZ, Lilia Moritz. História da vida privada no Brasil. contrastes da intimidade contemporânea. São Paulo: Companhia das Letras, 1998.v. 4, p. 319-409. 
ALVES, Maria Helena Moreira. Estado e oposição no Brasil (1964-1984). Petrópolis: Vozes, 1989.

AQUINO, Maria Aparecida de. Caminhos cruzados. imprensa e Estado autoritário no Brasil (1964-1980). Tese (Doutorado em História Social) — Faculdade de Filosofia, Letras e Ciências Humanas, Universidade de São Paulo, São Paulo, 1994.

; MATTOS, Marco Aurélio Vannucchi Leme de; SWENSSON JR., Walter Cruz (Org.). Radiografias do autoritarismo republicano brasileiro. São Paulo: Arquivo do Estado de São Paulo/Imprensa Oficial, 2002. 5 v.

ARENDT, Hannah. Crises da República. Tradução de José Volkmann. 2. ed. São Paulo: Perspectiva, 2004.

BELTRÃO, Luiz. Jornalismo opinativo. Porto Alegre: Sulina, 1980.

BÍBLIA. N. T. João, 16, 33. In: BÍBLIA. Português. Bíblia Sagrada: contendo o Antigo e o Novo Testamento. Tradução de João Ferreira de Almeida. Rio de Janeiro: Sociedade Bíblica do Brasil, 1966.

CORDEIRO, Janaína Martins. Anos de chumbo ou anos de ouro? A memória social sobre o governo Médici. Estudos Históricos, Rio de Janeiro, v. 22, p. 85-104, 2009.

CRUZ, Heloisa Faria; CUNHA, Peixoto Maria. Na oficina do historiador. Conversa sobre história e imprensa. Projeto história, São Paulo,n. 35, p. 253-270,2007.

FONSECA, André Dioney. "Temei a Deus, honrai ao Rei": revista $A$ Seara e os (des)caminhos do debate sobre a relação Igreja/política na imprensa assembleiana (1956-1980). Tese (Doutorado em História Social) - Faculdade de Filosofia, Letras e Ciências Humanas, Universidade de São Paulo, São Paulo, 2017.

HAMBURGER, Esther. Diluindo fronteiras: a televisão e as novelas no cotidiano. In: NOVAIS, Fernando Antonio; SCHWARCZ, Lilia Moritz. História da vida privada no Brasit. contrastes da intimidade contemporânea. São Paulo: Companhia das Letras, 1998. v. 4, p. 439-487.

JOFFILY, Mariana. No centro da engrenagem: os interrogatórios na Operação Bandeirante e no DOI de São Paulo (1969-1975). 1. ed. Rio de Janeiro: Arquivo Nacional; São Paulo:Edusp, 2013.

LANGLAND, Victoria. Speaking of flowers. student movements and the making and remembering of 1968 in Military Brazil. Durham: Duke University Press, 2013.

LUCA, Tania Regina de. História dos, nos e por meio dos periódicos In: PINSKY, Carla B. (Org.). Fontes históricas. São Paulo: Contexto, 2006. p. 111-153.

MAGALHÃES, MarionildeBrepohl de. Fazer falar: técnicas de interrogatório durante o regime militar. In: CANCELLI, Elizabeth (Org.). Histórias de violência, crime e lei no Brasil. Brasília: Universidade de Brasília, 2004. p. 155-172.

MARTINS, Ana Luiza. Da fantasia à história: folheando páginas revisteiras. Revista Nera, Unesp, v. 22, p. 59-79, 2003.

MARTINS FILHO, João Roberto. Movimento estudantil e ditadura militar, 1964-1968. Campinas: Papirus, 1987. 
MATTOS, Marco Aurélio Vannucchi Leme de; SWENSSON JR., Walter Cruz. Contra os inimigos da ordem. a repressão política do regime militar brasileiro (1964-1985). São Paulo: DP\&A, 2003.

NAPOLITANO, Marcos. 1964: história do regime militar brasileiro. 1. ed. São Paulo: Contexto, 2015.

OLIVEIRA, Joanyr de. Memorial do sobreviventeautobiografia e poemas. Brasília: ALB, 2008.

PRADO, Luiz; EARP, Fábio. O milagre brasileiro: crescimento acelerado, integração internacional e concentração de renda (1967-1973). Rio de janeiro: Civilização Brasileira, 2003.

REIS FILHO, Daniel Aarão. Ditadura militar, esquerdas e sociedade. Rio de Janeiro: Jorge Zahar, 2000.

RIDENTI, Marcelo Siqueira. Intelectuais e artistas brasileiros nos anos 1960/70: entre a pena e o fuzil. ArtCultura: Revista de História, Cultura e Arte, UFU, v. 9, n. 14, 2007. . O fantasma da revolução brasileira. São Paulo: Unesp, 1993.

; ANTUNES, Ricardo. Operários e estudantes contra a ditadura: 1968 no Brasil. Mediações. Revista de Ciências Sociais, v. 12, n. 2, 2007.

SILVA, Tadeu AntonioDix. Ala Vermelha: revolução, autocrítica e repressão judicial no estado de São Paulo (1967-1974). Tese (Doutorado em História) — Programa de Pósgraduação em História Social, Universidade de São Paulo, São Paulo,2007.

SIRINELLI, Jean-François. Os intelectuais. In: RÉMOND, René. Por uma história política. Tradução de Dora Rocha. 2. ed. Rio de Janeiro: FGV, 2003. p. 231-269.

SKIDMORE, Thomas. Brasit. de Castelo a Tancredo. Tradução de Mario Salviano Silva. Rio de Janeiro: Paz e Terra, 1988.

Fontes

A SEARA. Atenção juventude cristã.Editorial, n. 83, mar. 1970. Inquietação.Editorial, n. 84, abr./maio 1970. Lares incendiados.Editorial, n. 76, maio/jun. 1969. Que tempos são êstes?.Editorial, n. 85, jun.1970.

André Dioney Fonseca: Professor Adjunto do Curso de História da Universidade Federal do Oeste do Pará (UFOPA). Doutor em História Social pela Universidade de São Paulo (USP). 


\section{Como citar este artigo (Howto cite thisarticle):}

FONSECA, André Dioney. "Tempos de Inquietação": o contexto de 1968 nas páginas da revista A Seara da Igreja Assembleia de Deus. In REVISTA TRANSVERSOS. "Dossiê: Histórias e Culturas Afro-Brasileiras e Indígenas - 10 anos da Lei 11.645/08 ". Rio de Janeiro, $\mathrm{n}^{\circ}$. 13, MAl-AGO, 2018, pp. 201-225. Disponível em: <http://www.epublicacoes.uerj.br/index.php/ transversos $>$ ISSN 2179-7528. DOI:10.12957/transversos.2018.36458.

\section{Re $/$ ista
Trans}

